\title{
Creation of the new financial universe in Japan through Big Bang by Hiroshi Naka
}

$\mathrm{O}$ n 11 November 1996, Prime Minister Ryutaro Hashimoto instructed the Finance and Justice Ministers to 'reform the Japanese financial system fundamentally and make the Japanese market free, fair and global.' It was then that the Japanese financial Big Bang, named after London's 1986 Big Bang, began.

From 1 April 1998, the new Foreign Exchange Control Law was enacted. Almost all restrictions dividing the domestic financial market from the overseas market were abolished. Japan forced herself into the position where a huge amount of capital will inevitably leave Japan and her financial market will be hollowed out unless reform is accomplished rapidly. This new law was a 'down-payment' to foreign financial institutions disappointed at past promises of liberalisation.

Many instances are now being seen of full-scale entry into the Japanese market by foreign financial institutions, for example:

- a tic-up between Bankers Trust and The Nippon Credit Bank;

- joint establishment of a new life insurance company by GE Capital and Toho Mutual Life;

- entry into the retail securities business by Merrill Lynch through taking on 2,000 employees of the failed Yamaichi; and

- an alliance between Travellers Group and Nikko Securities.

These foreign financial institutions are aiming to penetrate businesses such as the management of $¥ 1,200$ trillion of financial assets held by Japanese individuals and areas such as investment banking.

Japanese financial institutions must survive the positive consequence of greater competition while overcoming the other more negative result of the financial crisis caused by the serious asset problem following the burst of the bubble in the early 1990s. In mid-1998 an alliance between The Industrial Bank of Japan and Nomura Securities was announced. This was the first case of an alliance among major Japanese financial institutions and this particular combination was beyond expectations. It showed that the great competition had already commenced.

A significant change has occurred in the regulatory system as well. On 22 June 1998, the Financial Supervisory Agency (FSA) was established as a supervisory authority independent from the Ministry of Finance. In addition, the Financial System Reform Bill was passed by the Diet on 5 June 1998. Many of the measures planned were in this bill but, of course, not everything was included. Further measures will follow to complete the Big Bang process by March 2001. For Japan, the term 'Big Bang' now means not only financial system reform but extends also to social reform.

This article examines the whole picture of the Japanese Big Bang from three perspectives:

- What pressures induced this explosion?

- Are the detonations disorderly without any law?

- How will it change the Japanese social system?

\section{THE THREE PRESSURES}

To begin with, an analysis is required of what sort of pressure induced this Big Bang. At the very beginning of the universe the Big Bang is said to have resulted from gravity concentrating on a point that could not endure its huge weight and extremely high pressure. In the context of the Japanese financial system, what pressure is equivalent to gravity? Three kinds are to be found.

The story goes back not 15 billion years but to about 50 years ago. At that time Japan needed to recover as quickly as possible from the damage of World War II. A new financial architecture was designed, as well as a strategy to allocate the low level of savings efficiently to target industries. Thus the Japanese financial system, characterised as business segmentation with interest rate regulation, was established. In this system, indirect finance is the major means of financing, with direct financing as a supplemental means. Short-term credit for corporate operation is supplied by commercial banks such as large city banks and regional banks. Long-term credịt for corporate investment is supplied by long-term credit banks, trust banks and life insurance companies. Business in the capital market is left to securities companies. For a long time this financial system functioned very well and supported the high economic growth rate through the efficient allocation of savings.

\section{The first pressure}

After the two oil shocks of the 1970s, however, Japanese economic growth rates stabilised, with lower figures, and the direction of the flow of funds changed dramatically. The large funds accumulated by the high savings rate flowed less into private sector investment and much more into the government bond market to finance the mounting budget deficit. Large Japanese corporations slowly acquired the capability to raise funds directly from the capital market, so that disintermediation (the gradual decrease of the acquisition of finance/funds through intermediaries) gradually progressed. Under such circumstances the financial system, with its segmented financial sectors, showed an inability to allocate funds efficiently. This became the first pressure to induce the Big Bang.

In response to this pressure, in 1992 a partial review was carried out and cross-entry among banking, trust and securities businesses through subsidiaries was allowed. It had become obvious that a financial system characterised by segmented businesses required lots of regulations to designate boundaries between businesses, thus reducing the possibilities for free market activity by financial institutions.

\section{The second pressure}

While Japanese financial institutions have been tied up in complicated regulations and competing for enlargement of business volume with other Japanese institutions in the same sector, the world financial industry has been introducing various advanced financial technologies and improving business quality 
dramatically. The Japanese financial industry has been left behind in the rapid development of financial innovation and has gradually lost its international competitiveness. The status of the Tokyo market as an international financial centre has also declined. There is real concern anong policy-makers and people working in the financial sector over the hollowing out of the Tokyo market and the ability to create jobs by the Japanese financial industry. This became the second pressure.

\section{The third pressure}

The third pressure comes from the rapidly ageing Japanese population, the growth of which is unprecedented in human history. A demographic survey shows that, in the Japan of 2025, one pensioner over 65 years old will be supported by only two workers. In order to support its old people Japan must ensure that the $¥ 1,200$ trillion of financial assets held by individuals is invested wisely, but more profitably, through public and private pension schemes and saving plans. However, its interest rate has hit an historic low of almost $1 \%$, lower than the previous record of bond yields of Genoa in the 17th century. In the US, the financial revolution of the 1970s was a result of high inflation. In Japan today, the ageing population and historically low interest rate strongly demand financial revolution.

These three pressures have been building up during the first half of this decade. A critical point was reached in November 1996, and at that time Prime Minister Hashimoto judged that it was impossible to ease these hugely accumulated pressures by gradual deregulation and decided to release the pressure in the form of a Big Bang.

\section{THE WAY AHEAD: REFORM OF FINANCIAL SYSTEMS}

Did Big Bang at the beginning of the universe occur in a disorderly way? No - it followed the laws of physics. Will the Japanese Big Bång simply destroy the existing financial regulations and system? Again, the answer is no. There are laws or principles to be followed.

\section{Deregulation}

Firstly there is the principle of the promotion of competition in financial services by radical deregulation. As has been said, many regulations were necessary to sustain the framework of the segmented financial system and to keep the system sound, but these regulations had become obstacles to competition. Now there is a need to make Tokyo an advanced financial centre like London and New York. Japan's financial industry must provide its ageing society with the best possible quality of asset management services. The Japanese financial system must be made as efficient as possible in terms of the transfer mechanisms of flows of funds. To achieve these goals there is also a need to deregulate dramatically and promote greater competition among the financial service providers. Severe competition will encourage innovation and a higher quality of financial services.

The Japanese often talk of the 'Wimbledon effect' on the City of London after the British Big Bang. Just as the traditionally British Wimbledon tournament has, for many years, been dominated by non-British players, so foreigners have come to own former British institutions. In Britain there is little bad feeling about such developments, but in Japan people do still feel a certain sentimentality. This has to be overcome: and will be.
The promotion of freer competition means that the Japanese financial system will function on the basis of the market mechanism. The former system, with separated business sectors, was a system that was suitable for allocating funds to certain target industries. But radical deregulation - one of the principles of Big Bang - is aiming at a total change in the characteristics of the Japanese financial system.

Briefly, I would like to point out some areas of progress. There have been radical changes in the financial environment, for example in investment trusts, financial derivatives, securitisation of real estate, business scope of securities companies, liberalisation of prices, tax reform and competition between exchanges.

To take just one of these areas, all obstacles concerning financial derivative products have been removed. There had been legal ambiguities concerning financial derivatives: in the case of contracts for differences, which means that settlement of contracts is carried out without any delivery of related property, they could possibly have been regarded as a form of gambling prohibited under the Criminal Code. The condition for a certain type of transaction to be exempt from the application of this gambling clause is that it must be authorised by a law other than the Criminal Code. Although all types of contracts for differences traded in the exchanges were already authorised in related laws, most types of over-the-counter contracts for differences were not. Therefore such OTC derivatives, including forwards, swaps and options, have been defined in a very comprehensive way in the Banking Law, the Financial Futures Transaction Law and the Securities and Exchanges Law, etc. Banks, broker-dealers of financial futures, securities companies, etc., have been authorised to do business in these. On the other hand, contracts for differences without any such authorised financial intermediaries as either party are probably illegal.

The segmented financial system - the biggest issue of deregulation - will be substantially modified simply by every type of financial institution acquiring the ability to provide similar financial products and services through radical deregulation, and liberalisation of products in particular. The barriers which had institutionally segmented the business sectors will be lowered by allowing cross-entry through subsidiaries and by the utilisation of the recently introduced financial holding company system. The financial holding company will be the best tool for pursuing economies of scale or scope through mergers and acquisitions, restructuring businesses by outsourcing business to a subsidiary or selling a non-profitable business. The map of the Japanese financial industry will change quickly after the Big Bang. Several gigantic conglomerates, many financial boutiques, and other financial institutions of diverse character can be expected to take their places on that map.

\section{Reregulation}

The second principle of Big Bang is 'reregulation'. In a sense, reregulation contradicts deregulation. But it is necessary in the Big Bang process to study what means of public intervention in the financial industry can be justified and to review regulations in consequence. In this sense Big Bang is reregulation as well as deregulation and they are not contrary to one other. What are the reasons behind public intervention in the financial industry? There are three areas of legal interest to be protected. First, 
avoidance of systemic problems arising in the financial system; secondly, protection of consumers such as depositors, investors and policyholders and, thirdly, maintenance of fair trade. These three interests have long been recognised in Japan just as in other industrialised nations. They will not be changed by Big Bang, although public intervention will, however, be executed using different methods.

In what direction are these methods to be changed? First, the Financial Supervisory Authority (FSA) trusts market discipline and requires consumers to take more responsibility for their decisions. Secondly, if there is any sort of fault or failure found in the financial market, the authority promptly and transparently deals with the case according to pre-set and pre-announced rules. In other words, Japanese regulators and supervisors will transform the methods of administration from handling issues in advance, with room for discretion, to ex post facto handling of issues based on pre-set rules, from industry-oriented to marketoriented, and from domestic to global standards.

\section{REGULATION OF THE FINANCIAL SYSTEM}

Formerly, systemic problems had been avoided and consumer protection ensured by allowing excess profit in each financial sector while imposing minute and detailed restrictions on the activities of financial institutions. In this way the authority ensured the sound operation of each institution. More precisely, maintaining the balance between various business sectors and between the financial institutions within each sector was seen as vital for financial stability; this balance warranted detailed restrictions and guidance, using the authority's business boundary-drawing power. In the case of failure of an institution in a certain business area, the authority planned a rescue merger of the institution by another strong institution in the same business area under the so-called 'convoy system'.

As to financial administration and supervision, the biggest change is the reorganisation of the Ministry of Finance (MOF). The MOF had the dual functions of planning and supervision relating to the Japanese financial system. On 22 June 1998, however, the supervisory function was transferred to the FSA, a newly established agency of 403 staff members, which is under the Prime Minister's office and independent of the MOF. The non-ministerial Commissioner of the FSA is a former public prosecutor, Mr Hino. The planning function has been left in a new bureau of the MOF, the Financial System Planning Bureau (FPB), integrating the banking and securities bureaux. The prevailing view is that this reorganisation is political. It is said that the reorganisation was the result of one of the reviews of the role of the Japanese bureaucracy and aims to weaken the MOF, the 'ministry of ministries', by partially depriving it of authority. It is also said that it was as a penalty for failure to maintain financial system stability that the ministry lost authority over supervision and inspection.

When the Big Bang process is completed in 2001, the MOF will be reorganised again as part of an overall organisational reform of the Japanese 'Whitehall'. It will lose almost all of its financial system planning function and will probably be renamed the 'Treasury'. The only function left in this Treasury will be that related to financial crisis management. Meanwhile the FSA will have full authority over the financial system and will be headed by a minister with full responsibility for financial stability. How do we interpret this reorganisation? Why will financial crisis management be shared? This is probably because the Treasury is expected to be a kind of watchdog over the FSA. Supervisors tend to use forbearance when faced with the symptoms of a financial crisis because it is very hard for them to admit their supervisory failure. So a kind of watchdog is needed. In the UK, HM Treasury shares responsibility over systemic risk with the Financial Services Authority and the Bank of England based on a Memorandum of Understanding. However, in reality it is perhaps fair to say that the Treasury is expected to be such a watchdog.

\section{Changes in supervisory methods}

What changes will be seen in supervisory methods? The most important is the introduction of PCA (prompt corrective action). The idea of PCA comes from the US. Supervisors order a bank to take pre-set corrective actions when its financial situation deteriorates to a certain stage. Such levels of financial condition are judged by objective measures such as the capital adequacy ratio. At the worst stage of excess liabilities the bank will be ordered to suspend its business. PCA, therefore, is an early cure, the need for which is judged by an objective medical check. In order to know the accurate capital adequacy ratio, a bank itself must assess the value of its assets and then certified public accountants (CPAs) and FSA bank inspectors examine that self-assessment. A similar idea is to be introduced for insurance and securities companies. On-site inspection will be improved, with inspectors placing more importance on internal risk control systems as well as the quality of assets. Supervisors will be tougher in using legal measures against financial institutions if they find something that needs to be improved.

A more transparent process of financial system planning will be seen. The FPB will publish a consultation paper to collect public comments when they decide on significant rule changes. Under the industry-oriented regime, comments were collected only from industrial associations like that of the Federation of Bankers; there is now a requirement to invite comments from various foreign financial institutions, Japanese consumers and others.

The role played by the Bank of Japan in maintaining financial stability has been clear. The new Bank of Japan Law, enacted from April 1998, reveals that one of the bank's purposes is to operate the clearing and settlement system and maintain its stability It also has powers to supply liquidity without collateral in the case of an institutional emergency, like a computer system crash, and to supply liquidity with special terms in case of systemic problems arising from failure of a financial institution. This special lending is executed on acceptance of a request from the Finance Minister, based on consultation with the FSA Commissioner. In addition, the examination of financial institutions, which had legal ambiguity under the previous Bank of Japan Law, has been authorised for the first time as a means for the bank to maintain the stability of the clearing and settlement system. Although it has no authority of supervision over each financial institution, the bank is expected to share a certain responsibility for the stability of the clearing and settlement system, which is to say, the financial system.

\section{CONSUMER PROTECTION}

The second area of legal interest is that of consumer protection. The framework for the protection of consumers 
such as depositors, investors, and policyholders has been strengthened with the viewpoint that consumers should take more responsibility for their decisions. However, in order for consumers to make responsible judgments, it is important to provide proper information on financial institutions and products. Requirements for banks' disclosure to depositors have therefore been strengthened and this previously voluntary disclosure has been made a legal obligation under the Banking Law. Managers or employees of a bank who fail to disclose or commit false disclosure of items such as the amount of bad loans can be individually penalised and the bank itself will be sanctioned. Securitics companies and insurance companies are subject to similar obligations. Regarding the disclosure of bad loans, the definition used by the major money-centre banks, as from the financial year ended March 1998, is now compatible with global standards (if American SEC standards can be called global).

Another issue of disclosure relating to the issuance of securities and so on will also make much progress. The rules will be amended to require consolidated disclosure covering both parent and subsidiary companies. Accounting standards for research and development will be equivalent to global standards. What is being discussed now includes the expansion from financial institutions to companies in general of utilisation of the mark-to-market method of evaluating financial instruments. Recently the accountancy office for the failed Yamaichi Securities faced a lawsuit brought by shareholders on the grounds that the office missed the huge amount of loss concealed off balance sheet. It is likely that this kind of legal trial will improve the quality of audits by CPAs

One more comment on disclosure. Financial institutions have been required to explain schemes fully to consumers, including the potential risks of financial products, at point of sale. In Japan there are many cases of the mis-selling of life-insurance products with no guarantee for principal. These products were sold by insurance companies, with the co-operating banks' backing finance, to those who wanted tax plans to cope with the heavy inheritance tax duty resulting from the asset bubble. Some insurance companies and banks have been criticised for not fully explaining the risks implied in the products and the tax plans.

\section{DISPUTE-SETTLEMENT SYSTEM ENHANCED}

The dispute-settlement system for problems between securities companies and their customers has been enhanced Previously, customers could ask the MOF to mediate on their behalf with the securities companies concerned. To achieve a more effective and easier to use dispute settlement system, a new system has been introduced, whereby customers can ask a committee, members of which are selected from outside of the securities industry by the Securities Dealers Association, a selfregulatory organisation, to arbitrate. The securities companies concerned must obey the arbitration unless they file the case in court. As yet, there is no such dispute-settlement system in the banking and insurance sectors. This is a future task which may benefit from a study of the UK's experience, where the disputesettlement system is to be transferred from self-regulatory organisations (SROs) to the Financial Services Authority (FSA).

With very strong competition brought about by radical deregulation and greater reliance on market discipline, failures of banks and other financial institutions are inevitable. If the principle of consumer self-responsibility is fully applied, consumers have to accept $100 \%$ of their losses. However, because consumers are not always given full information, both at the point of sale and afterwards, it is unfair to ask them to carry $100 \%$ of their losses. The authority has to enhance consumer protection measures to prepare for failures of financial institutions.

Bank deposits are protected by the Deposit Insurance Corporation, which guarantees up to $¥ 10 \mathrm{~m}$ to each depositor and gives financial assistance to a bank which rescues a failed bank by merger or acquisition. This is why Japan has also strengthened safety nets for investors and policyholders.

As for investor protection, the Securities Investor Protection Fund - a public institution - has been established under the Securities and Exchange Law. Securities companies are obliged to join the new Fund. The ceiling on compensation to any one customer is expected to be $¥ 10 \mathrm{~m}$, with the definition of customers to be protected excluding professional investors, such as institutional investors. In addition, special provisions have been provided to permit the fund to act as a proxy for customers in bankruptcy or reorganisation procedures for securities companies, as with banks. Legal obligations have also been set for customer assets to be managed separately from company assets, in order to protect investors in the event of a securities company failure. If this separation works well, the financial burden on the fund will be lighter.

The Policyholder Protection Corporation has been created to replace the Policyholder Protection Fund, which protected policyholders by providing financial assistance to the relief insurance company, which helped a failed insurance company by taking on its portfolio. The corporation has been given the new function of accepting the portfolio of a failed insurance company should no relief insurance company come forward. When the corporation takes on portfolios directly, it can cut the dividend rates promised by the failed insurer. The corporation guarantees the insurance payments up to $90 \%$ of the technical reserves which should have been held for future insurance payments by the failed insurer.

In order to avoid moral hazard, these safety nets do not always guarantee $100 \%$ of the claims held by depositors, investors, or policyholders. In some cases, consumers have to take responsibility for their own choices. However, until the end of March 2001 when the Big Bang process is complete, deposits, securities in custody, and insurance policies will be 100\% protected because this period is seen as the transition period for meeting the preconditions of the principle of self-responsibility. The Deposit Insurance Corporation already has $¥ 17$ trillion of special funds available to use in this period and backed by the Government. The Securities Investor Protection Fund and the Policyholders Protection Corporation will also have access to sufficient funds over this period, backed by the Government.

\section{FAIR TRADE}

Prevention of unfair trading in which financial intermediaries were involved had been ensured by giving directions to such intermediaries, not by legislation. A license was required to establish a securities company, and it was thought that a licensed institution could be appropriately directed by the MOF. Legal 
rules therefore were not always seen as necessary and administrative guidance was enough. For example, in the scandal of 1991, the covering of investors' losses by securities companies was not illegal because it was not prohibited by law. However, there was an administrative guidance prohibiting such action.

Therefore, as the liberalisation of the securities market moves ahead, it must be ensured that markets are fair and trustworthy, and that investors are able to trade in them with confidence. Fair trading rules have been formulated and enhanced to prevent unfair trading activities, the spreading of rumours, market manipulation and insider trading as the markets adapt to the introduction of OTC derivatives on securities and so on. This includes forfeiture of illicit profits by unfair trading practices such as insider trading. Many measures to prevent conflict of interest have also been introduced in the Securities and Exchange Law. Conflict of interest is nothing new. In the 1992 financial system reform, conflict of interests between banks and their securities subsidiaries was one of the main topics and various firewalls were built. Now, since one financial body can operate more and more businesses simultaneously, this issue has become even bigger. Although tough competition itself could be a pressure preventing conflicts of interest in a company, it appears that the authority needs to deal carefully with this issue.

Money-laundering is also an important issue, especially as the financial market is integrated in the global market. In the amendment to the Foreign Exchange Control Law, the procedure of export and import of cash or securities denominated in yen or foreign currency of more than $Y ¥ 1 \mathrm{~m}$ was tightened and money-changers were required to identify customers in exchanges of more than $¥ 5 \mathrm{~m}$. International transfers of funds exceeding $¥ 2 \mathrm{~m}$ must be reported by banks to tax offices. The FSA also established the post of Administrator for Financial Intelligence Management. The administrator is in charge of collecting, processing, analysing, and providing information on suspicious transactions to relevant investigatory agencies.

\section{FURTHER READING}

See Issue 6 (April 1998), p. 7, for comment on the Japanese Big Bang by Hiroshi Goto, and Issue 7 (May 1998), p. 31, for an article by Koji Takahashi on shareholders' derivative actions.

\section{SOCIAL CONSEQUENCES}

Finally, a brief explanation of social change which, whilst not exactly a principle, is an inescapable consequence of Big Bang. The explanation focuses on the impact of Big Bang on three relationships:

- those between corporations and their shareholders;

- their employees; and

- with other companies.

In this regard, the enhancement of corporate governance must first be underlined. Shareholders in Japan have long been accustomed to low rates of income gains. This is perhaps partly because income gains were much lower than capital gains during the two decades of rapid economic growth. It may also have to do with the attitude of the management of Japanese companies toward sharcholder meetings; they needed silent shareholders and therefore increased cross-shareholdings. But times have changed and shareholders have become gradually more vocal in their criticism. There have been many cases of shareholders filing lawsuits against directors who have damaged their companies, taking advantage of streamlined procedures for such lawsuits. Some foreign shareholders have demanded more from management. Under these circumstances many Japanese managers have emphasised the need to improve indicators such as returns on equity which, although familiar elsewhere, has in Japan only recently become common. However, even if the Japanese government reforms the capital market, it cannot be attractive to investors without good corporate governance.

Changes will also be seen in the relationship between corporations and their employees. Like financial institutions in Wall Street, Japanese financial institutions will have to pay more than 'bar' or $\$ 1 \mathrm{~m}$ bonuses to specialists such as financial engineers. Even in Japan headhunting in the financial industry has been acknowledged as a 'daytime' job. Nowadays headhunters are said to receive almost the same number of requests from Japanese as from foreign financial institutions operating in Japan. It does not seem necessary to abandon the lifetime employment system in all Japanese companies, but it is cssential for Japanese financial institutions doing wholesale business to employ more highly skilled workers from a more flexible labour market. Unless they do so, Japan will see the hollowing-out of its excellent human resources and Big Bang will not succeed.

We will also see changes in the relationships between companies. Business depending overly on long-term relations between companies will gradually disappear. In particular, the main bank system, which has supported associated corporations as a lender of last resort, will be modified. The status of semimain banks at least can be expected to totally disappear totally, and the main banks will not be able to get involved in every business offer from associated corporations just because of their status as main banks. Although it does not scem desirable to throw away long-term business relationships, it appears favourable to see full competition in quality of service without over-reliance on long-term relationships.

\section{CONCLUSION}

To conclude, the Big Bang provided a reminder of one of the main lessons from the East Asian currency crisis: that the financial system in any country is inevitably affected by the advanced financial centres in this globalised financial world. The Japanese Big Bang seems to be difficult for Japan to implement because it breaks all the established orders. But from the global perspective it is just a matter of course, so it simply has to be implemented.

In the final stage of the Japanese Big Bang process, a financial services law that integrates Banking Law, Securities and Exchange Law, Insurance Law and so on will probably be needed. Will reference be made again to the UK model?

\section{Hiroshi Naka}

Resident Director, Research Institute for International Investment and Development, The Export-Import Bank of Japan

This article is based on an address given on 2 July 1998. 